\title{
Potential impact on bacteria of grazing by a macrofaunal deposit-feeder, and the fate of bacterial production
}

\author{
Paul F. Kemp* \\ Oregon State University, Hatfield Marine Science Center, Newport, Oregon 97365, USA
}

\begin{abstract}
Bacterial biomass and production were compared to the carbon requirement and sediment processing capability of the deposit-feeding polychaete Euzonus mucronata (Treadwell) on a sand beach in Oregon, USA. Mean bacterial abundance ranged between sampling dates from 5.2 to $12.0 \times$ $10^{7}$ cells g ${ }^{-1}$ sediment and mean biomass ranged from 1.5 to $3.4 \mu \mathrm{g} \mathrm{C} \mathrm{g}^{-1}$ sediment $(0.36$ to $0.84 \mathrm{~g} \mathrm{C}$ $\mathrm{m}^{-2}$ to $15 \mathrm{~cm}$ depth). Daily bacterial production based on tritiated thymidine incorporation on 7 December 1982 is approximately $55 \mathrm{mg} \mathrm{C} \mathrm{m}^{-2} \mathrm{~d}^{-1}$. The carbon requirement of $E$. mucronata, equal to the sum of annual production and respiratory loss of carbon, was 7.0 to $8.0 \mathrm{~g} \mathrm{C} \mathrm{m}^{-2} \mathrm{yr}^{-1}$ (19.3 to $21.9 \mathrm{mg}$ $\mathrm{C} \mathrm{m}^{-2} \mathrm{~d}^{-1}$. Although bacterial production exceeded the carbon requirement of E. mucronata, the low bacterial density limits direct utilization of bacterial carbon to $<10 \%$ of the average daily carbon requirement of $E$. mucronata, despite its relatively high sediment-processing capability. Conversely, $E$. mucronata ingests $<10 \%$ of bacterial production per day. Because of their low density, sediment bacteria are probably not a major carbon source to other sand beach macrofauna. Bacterial turnover times (mean $=10 \mathrm{~d}$ ) were similar to reported turnover times at much higher cell densities in other sediments, indicating that bacterial production exceeds macrofaunal production by one or more orders of magnitude in many environments. It is likely that macrofauna seldom consume more than a few percent of benthic bacterial production. Future studies of the fate of benthic bacterial production should examine the role of microbial and meiofaunal grazers.
\end{abstract}

\section{INTRODUCTION}

Some macrofauna efficiently remove and assimilate bacteria from sediment and detritus (Newell 1965, Hargrave 1970a, Hylleberg 1975), while at least some types of detritus may be very refractory (Newell 1965, Fenchel 1970, Fenchel \& Blackburn 1979). This comparison led to the hypothesis that bacteria are the primary food resource of deposit-feeding macrofauna. The hypothesis has since been challenged by studies which showed that the amount of bacterial biomass actually ingested was not sufficient to supply the carbon requirements of deposit-feeding macrofaunal species (Baker \& Bradnam 1976, Wetzel 1977, Cammen 1980a, Jensen \& Siegismund 1980, Levinton \& Bianchi 1981, Hammond 1983). It is now generally accepted that bacteria are not the principal food source of many,

\footnotetext{
- Present address: University of Georgia Marine Institute, Sapelo Island, Georgia 31327, USA
}

if not all macrofaunal detritivores, and research on the food resources of deposit-feeders has tended to shift to microalgae, available detritus, and the utilization of relatively refractory detritus (Tenore et al. 1982, Levinton et al. 1984, Carman \& Thistle 1985, Smith et al. 1985, Stuart et al. 1985, Kemp 1986).

Recent research on interactions between bacteria and benthic fauna continues to focus on defining the role of bacteria as a potential food resource (e.g. Findlay et al. 1984, Phillips 1984, Carman \& Thistle 1985). Relatively little is yet known of the actual or potential effect of macrofaunal grazing on bacteria. Macrofaunal grazing at realistic levels can stimulate bacterial activity (Hargrave 1970b, Morrison \& White 1980); bacterial densities may not be reduced by macrofaunal grazing (Levinton \& Bianchi 1981) except at macrofaunal densities greatly in excess of natural densities (Hargrave $1970 \mathrm{~b}$, Moriarty et al. 1985). In the present study the carbon requirements and ingestion rate of the deposit-feeding polychaete Euzonus mucronata 
(Treadwell) are compared to bacterial biomass and production, in order to evaluate the potential impact of macrofaunal grazing on bacteria as well as the potential utilization of bacteria by E. mucronata. Methods for measuring bacterial production are relatively new and, with the exception of Moriarty et al. (1985), estimates of benthic bacterial production have not been compared to the potential utilization of bacteria by benthic macrofauna.

The specific goals of the present study were to: (1) determine whether bacterial biomass could be a significant food resource of Euzonus mucronata; (2) determine the fraction of bacterial production which could be grazed by E. mucronata; and (3) evaluate the role of macrofaunal grazing on bacteria based on this information.

\section{METHODS}

Site description. The study species, Euzonus mucronata, is very abundant in the upper intertidal of highenergy sand beaches of the northeastern Pacific, dominating macrofaunal biomass and numbers in the elevations at which it occurs. The study site was the upper intertidal of a sand beach $7 \mathrm{~km}$ south of Yaquina Bay, Oregon, USA $\left(44^{\circ} 33.8^{\prime} \mathrm{N}, 124^{\circ} 04.4^{\prime} \mathrm{W}\right)$. The $E$. mucronata population at the site is located in a sharply delineated region between the lower and extreme high water levels, herein referred to as the Euzonus 'band'. Tides are semi-diurnal with a maximum daily amplitude of about $3 \mathrm{~m}$. Sediment is well-sorted medium-fine sand $(0.27 \mathrm{~mm}$ median grain size; Bosworth 1976 ) with 0.5 to $0.7 \%$ organic matter (ash-free dry weight). Nearshore water temperatures are 9 to $15{ }^{\circ} \mathrm{C}$ (Gonor et al. 1970) and sand temperatures were generally 9 to $15^{\circ} \mathrm{C}$ in the upper $15 \mathrm{~cm}$. Freshwater seepage occurs near the upper elevation limit of $E$. mucronata and at low tide can lower interstitial salinities to 6 to $7 \%$, grading to 32 to $34 \%$ at the lower elevation limit of the Euzonus band.

Ingestion, production and respiration of Euzonus mucronata. The sediment ingestion rate of E. mucronata was measured using direct observations of feeding individuals. An observation aquarium was constructed from two $15 \times 15 \mathrm{~cm}$ Plexiglas sheets separated by silicone tubing $(3.5 \mathrm{~mm}$ spacing when compressed), and held together by spring clamps. The silicone tubing was perforated on the inner surface and could be connected to a vacuum aspirator. The aquarium was filled with freshly collected sand from the study site. A 2 to $3 \mathrm{~mm}$ layer of sand dyed with methylene blue was embedded 5 to $10 \mathrm{~cm}$ below the sediment surface. Groups of 5 adult worms were taken directly from freshly collected sand and placed on the sediment surface, and usually burrowed directly or diagonally downward and encountered the dyed sand after 5 to $15 \mathrm{~min}$. All individuals observed $(>50)$ first burrowed entirely into the sediment, then began feeding while continuing to burrow. Three min after an individual was observed starting to ingest the bluedyed sand layer, formalin (final concentration $2 \%$ formaldehyde) was drawn through the sand. Worms were observed to stop feeding within $10 \mathrm{~s}$ and none were observed egesting sand in response to the formalin. The preserved worm was then cut into $2 \mathrm{~mm}$ sections and the gut contents of each section were examined. The total number of sections and the position along the body of the most posterior section containing bluedyed sand were used to estimate the rate at which sediment passes through the gut. Feeding experiments were conducted at $12^{\circ} \mathrm{C}$, approximately the annual average temperature at the study site.

Because feeding may have been affected by the confined nature of the observation aquarium, feeding in the observation aquarium was compared to feeding in a larger container. Ten worms were placed in the observation aquarium and allowed to pass blue-dyed sand entirely through the gut, displacing an easily identified plug of dyed sand a few centimeters from the layer of dyed sand. The distance the blue-dyed sand was displaced from the dyed sand layer was measured. The same individuals were then placed in a larger container $(10 \times 10 \times 20 \mathrm{~cm})$ of freshly collected sand with an embedded layer of blue-dyed sand $10 \mathrm{~cm}$ below the sand surface. The average linear displacement of ingested dyed sand in the larger container was compared to the average linear displacement in the observation aquarium. This displacement is related to the body length of the worm, its burrowing rate, and the rate at which sand passes through the gut by the equation:

$$
D=\left(B-L C^{-1}\right) C
$$

where $\mathrm{D}=$ displacement $(\mathrm{cm})$ of dyed sand (negative displacement is opposite to the direction of burrowing); $\mathrm{B}=$ burrowing rate while feeding $\left(\mathrm{cm} \min ^{-1}\right)$; L $=$ body length $(\mathrm{cm}) ;$ and $\mathrm{C}=$ time $(\mathrm{min})$ to pass sand through the gut. Thus, the displacement of dyed sand serves as an integrative measure of feeding and burrowing rate, and comparisons of sand displacement should be a reasonable means of assessing whether worms were feeding normally in the aquarium. As a second test of normal feeding, worms were placed in the larger container and allowed to burrow up and down for $12 \mathrm{~h}$ before carefully dissecting the sand to measure displacement of dyed sand above and below a dyed layer $10 \mathrm{~cm}$ below the sand surface.

The amount of sand retained in the gut was measured in 20 freshly collected individuals selected for a 
broad range in size. These were placed on the surface of fresh sand and allowed to burrow for $25 \mathrm{~min}$ to ensure that most of the individuals would have begun feeding. Formalin-seawater was then drawn through the sand and the preserved worms were dried at $70^{\circ} \mathrm{C}$, weighed, ashed at $500^{\circ} \mathrm{C}$, and reweighed to obtain dry and ash-free dry weights. After the ash was rinsed with dilute $\mathrm{HCl}$ followed by distilled water, the residual sand was dried and weighed.

The annual production of Euzonus mucronata within the band was estimated in a previous study (Kemp 1985, unpubl.) from samples collected on 9 occasions between 15 June 1980 and 22 June 1981. Abundance, biomass, and production estimates were expressed as number or grams of ash-free dry weight (AFDW) per linear meter of beach. For the present study, these values were converted to number $\mathrm{m}^{-2}$ or $\mathrm{g}$ AFDW $\mathrm{m}^{-2}$ by dividing by $18.3 \mathrm{~m}$, the average width of the $E$. mucronata band. Production was estimated separately for 2 cohorts, designated the pre-1980 and 1980 cohorts, distinguished in length-frequency distributions (Kemp 1985, unpubl.). Respiration in this study was also calculated separately for the 2 cohorts. Because the width of the $E$. mucronata band varied between sampling dates, respiration was also calculated from data on abundance per linear meter of beach and subsequently converted to an areal basis for comparison to bacterial production estimates.

The total respiration $\left(\mathrm{R}, \mu \mathrm{l} \mathrm{O}_{2} \mathrm{~m}^{-2}\right)$ during an interval between sampling dates can be estimated from the number of days in the interval, the mean number of individuals present during the interval, and the respiratory rate as a function of the mean weight of individuals during the interval and of environmental factors such as temperature and salinity. Total estimated annual respiration was defined as the sum of respiration during the intervals between samples starting 15 June 1980 and ending 22 June 1981. The mean number of individuals per meter of beach and their mean weight (as mg AFDW) during an interval were taken from the previous study, in which weight was estimated from measured length using a weight-length regression. Temperature and salinity were considered the 2 seasonally variable environmental factors which were likely to affect respiration rate. Respiration rate was measured with a Gilson respirometer in a factorial combination of 3 temperatures $\left(9,12,15^{\circ} \mathrm{C}\right)$ and 3 salinities $(6.5,16,32 \%)$, with 10 adult individuals ranging from 12 to $24 \mathrm{mg}$ body AFDW at each temperature-salinity combination. Temperature and salinity values were chosen to approximate the ranges observed in the field. The effect of body weight on respiration rate was examined at $12{ }^{\circ} \mathrm{C}$ and $6.5,16$, and $32 \%$, using individuals ranging from 1.4 to $51.4 \mathrm{mg}$ body AFDW. Worms collected in mid- to late summer were placed in Warburg respirometry flasks containing $10 \mathrm{~g}$ of oven-dried sand and $15 \mathrm{ml}$ of filtersterilized seawater and acclimated for $1 \mathrm{~h}$ to test temperatures and salinities. Controls with dried sand plus seawater had no measurable respiratory activity. In preliminary trials, worms in water without sand were abnormally active and had approximately 4 times the respiratory activity of worms in sand.

Production and respiration were converted to common units of carbon. Oxygen consumption was converted to an equivalent carbon loss by assuming a respiratory quotient of 0.9 (moles $\mathrm{CO}_{2}$ released per $\mathrm{O}_{2}$ consumed), equivalent to $0.482 \mu \mathrm{g} \mathrm{C}$ released per $\mu \mathrm{l} \mathrm{O}_{2}$ consumed (Cammen 1980a). Production as g AFDW $\mathrm{m}^{-2} \mathrm{yr}^{-1}$ was converted to $\mathrm{g} \mathrm{C} \mathrm{m}^{-2} \mathrm{yr}^{-1}$ by assuming that $50 \%$ of AFDW is due to carbon (Cammen 1980a).

Bacterial production. Bacterial production was measured by a tritiated thymidine (= thymine deoxyribose, Tdr) method. The method of Moriarty \& Pollard (1981) was used to obtain estimates of isotope dilution in each sample. Tests of the assumptions of this method indicate that the method produces reasonable predictions of bacterial growth rates in a chemostat system (Pollard \& Moriarty 1984). Although there has been considerable debate over the relative accuracies of various methods using tritiated nucleic acid precursors (e.g. Fuhrman \& Azam 1982, Moriarty \& Pollard 1982, Craven \& Karl 1984), the available comparisons of various procedures show reasonably close agreement between production estimates (Riemann et al. 1984). Since an approximate estimate of bacterial production would suffice in the present study, it is likely that any of the available methods would have been adequate.

Bacterial production was measured using subsamples of freshly collected and thoroughly mixed $15 \mathrm{~cm}$ long cores and was extrapolated to production per $\mathrm{m}^{2}$ to a depth of $15 \mathrm{~cm}$. Fifteen $\mathrm{cm}$ is approximately the depth to which the beach sand is mixed by wave action (Eikenberry 1966) and within which most of the macrofauna are found in the intertidal (Bosworth 1976, Kemp 1979, Hughes 1982) and nearshore subtidal (Oliver et al. 1980) of Pacific beaches. Interstitial water oxygen content was $>75 \%$ saturated within this layer when measured on 2 occasions (Kemp unpubl. data). Field observations on numerous occasions indicate that Euzonus mucronata is found within the upper 15 $\mathrm{cm}$ most of the time, although individuals infrequently descend to greater depths for one to several hours if immersed at high tide. Single cores $\left(8 \mathrm{~cm}^{2}\right)$ were collected at 5 elevations bracketing the Euzonus band in the upper to mid-intertidal on 7 December 1982. Cores were packed in sand to maintain the in situ temperature of $11^{\circ} \mathrm{C}$ and returned to the laboratory within 30 min. Each core was mixed thoroughly with a spatula after adding $25 \mathrm{ml}$ of $0.22 \mu \mathrm{m}$ filter-sterilized seawater 
at $11^{\circ} \mathrm{C}$ to facilitate mixing. Eight $2 \mathrm{~g}$ portions of sand were removed from each core for isotope dilution experiments. In addition, two $5 \mathrm{~g}$ portions were removed from each core and fixed in 10\% formalinseawater for bacterial enumeration and cell size measurements. One $\mathrm{ml}$ of $0.22 \mu \mathrm{m}$ filtered seawater, containing $1 \mu \mathrm{Ci}$ of ${ }^{3} \mathrm{H}-\mathrm{Tdr}\left(20 \mathrm{Ci} \mathrm{mmole}^{-1}\right)$ and varying amounts of unlabelled $\mathrm{Tdr}$, was mixed into replicate portions, which were then incubated for $45 \mathrm{~min}$ at $11^{\circ} \mathrm{C}$. Uptake of ${ }^{3} \mathrm{H}$-Tdr was linear at $11{ }^{\circ} \mathrm{C}$ for at least $60 \mathrm{~min}$ in preliminary experiments.

Incubation was terminated by the addition of $0.57 \mathrm{ml}$ of $1.0 \mathrm{~N} \mathrm{NaOH}$, which was added to controls prior to the addition of isotope. Samples were then heated at $100^{\circ} \mathrm{C}$ for $2 \mathrm{~h}$. The solution was transferred to a centrifuge tube with two $1 \mathrm{ml}$ rinses of hot $0.3 \mathrm{~N} \mathrm{NaOH}$ and centrifuged at low rpm to remove fine sediment particles. The supernatant was transferred to a glass vial, acidified with $3.5 \mathrm{mi}$ of concentrated ice-cold $\mathrm{HCl}$, and kept on ice for $45 \mathrm{~min}$. The precipitated DNA was collected on a $0.45 \mu \mathrm{m}$ Millipore HA filter and rinsed with $5 \mathrm{ml}$ of ice-cold $5 \%$ TCA. Collected DNA was hydrolyzed in a $15 \mathrm{ml}$ glass scintillation vial with

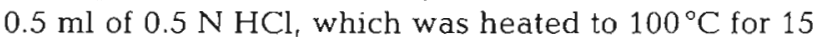
min. The filter was then dissolved in $1 \mathrm{ml}$ of ethyl acetate and the sample counted in $10 \mathrm{ml}$ of Aquasol-2 scintillant (New England Nuclear). Counting efficiency determined by internal and external standards was $42 \%$ and background in controls averaged $50 \mathrm{cpm}$ (due in part to retention of unincorporated label on the filter).

The efficiency of extraction of DNA from sediment was measured by mixing a solution of DNA $(0.5 \mathrm{mg}$ Escherischia coli DNA [Sigma] in $1 \mathrm{ml}$ of saline citrate solution) into $2 \mathrm{~g}$ of fresh sand and processing as described above. Samples of $0.3 \mathrm{ml}$ were removed for assay as described by Burton (1956) from the final solution prior to collection of precipitated DNA on the filter, and from the post-collection filtrate. The absorbance at $600 \mathrm{~nm}$ was compared to the absorbance of DNA standards.

Bacteria were removed from the sediment by homogenization at $23000 \mathrm{rpm}$ in a Viltis 45 homogenizer and enumerated by the AODC method (Hobbie et al. 1977). Homogenization speed was similar to that used by Dale (1974), Meyer-Reil et al. (1978), and Montagna (1982). The optimum time of homogenization was determined by homogenizing replicate $5 \mathrm{~g}$ portions from a mixed core for $30 \mathrm{~s}$, and 1, 2, 4, 10, and $15 \mathrm{~min}$. The number of cells recovered was greatest after 10 min. At 15 min, fragmented detrital matter was difficult to distinguish from red-fluorescing bacteria. For this reason, $10 \mathrm{~min}$ was selected as the optimum time of homogenization, in agreement with Montagna (1982). As a measure of seasonal variation in numbers, bacterial populations were also sampled and enumerated on 4 August 1982 and 7 April 1983.

Bacterial cells were photographed at $1260 \times$ using Kodachrome 400 slide film, which was later examined at $25 \times$ with a dissecting microscope. Cells were sorted into size categories and equivalent volumes were calculated as described by Rublee (1982). A conversion factor of $0.22 \mathrm{~g} \mathrm{C} \mathrm{cm}^{-3}$ biovolume was used to estimate bacterial carbon biomass (Bratbak \& Dundas 1984).

The density of wet sand $(18.5 \%$ water $)$ from the study site was $2.056 \mathrm{~g} \mathrm{ml}^{-1}$. This factor was used to convert bacterial biomass and production per gram of sand to the areal equivalents.

\section{RESULTS}

\section{'Euzonus mucronata ingestion rate}

The mean gut clearance time of 19 adult individuals ranging from 2.6 to $7.2 \mathrm{mg}$ AFDW (mean $5.05 \mathrm{mg}$ AFDW) was $3.375 \pm 0.342$ min (mean $\pm 95 \%$ confidence limits), and was not significantly correlated with body AFDW $\left(r^{2}=0.05\right)$. The mean displacement of dyed sand by 10 individuals was $-2.40 \pm 0.41 \mathrm{~cm}$ (in the opposite direction to burrowing) in the observation aquarium, and was not correlated to body AFDW. Mean displacement was $-2.91 \pm 0.27 \mathrm{~cm}$ in the larger container, not significantly different from the displacement in the observation aquarium. In the $12 \mathrm{~h}$ trial, mean displacement was $-3.41 \pm 0.26 \mathrm{~cm}(\mathrm{n}=55)$, significantly greater than in the observation aquarium. Greater negative displacement indicates shorter gut clearance times or slower burrowing rates than in the observation aquarium.

The mean weight of sand in the guts of 16 individuals ranging from 1.1 to $15.7 \mathrm{mg}$ AFDW, as percent of total body weight, was $57.7 \%( \pm 11.0 \%)$ of total dry weight (including sand) and $1.83( \pm 0.56)$ times the AFDW. There was no evident correlation between the dry or ash-free dry weights of individuals and the amount of sand in the gut expressed as a proportion of total body weight $\left(\mathrm{r}^{2}=0.06\right.$ for dry weight, 0.05 for AFDW). AFDW averaged $90.2 \%( \pm 6.6 \%)$ of the dry tissue weight, excluding sand; the proportion AFDW: $d$ ry weight varied slightly but significantly $(t=$ 4.97, $\mathrm{p}<0.001$ ) with dry weight:

AFDW (dry weight) ${ }^{-1}=-0.0152$ (dry weight, mg) + 1.0134, $\left(n=16, r^{2}=0.68\right)$.

The predicted ingestion rate for a typical adult (ca 10 mg dry weight) is therefore about $2.5 \mathrm{~g}$ dry sand $\mathrm{d}^{-1}$ or $15 \mathrm{mg}$ organic matter $\mathrm{d}^{-1}$. This ingestion rate is an order of magnitude higher than for other deposit feeders of similar size (cf. Cammen 1980b, Fig. 2) and could 
indicate a possible methodological error. For example, ingestion rates may be higher in short-term trials and when individuals are first placed in contact with sediment. However, observations of similar displacements of dyed sand in containers of different size and over short-term and $12 \mathrm{~h}$ test periods support the estimated ingestion rate. The ability of Euzonus mucronata to continue burrowing in drained sand when other macrofauna are immobilized (e.g. haustoriid amphipods, Kemp pers. obs.) may depend on removing sand from in front of the body by ingesting it and passing it rapidly through the gut.

\section{Euzonus mucronata production and respiration}

Expressed as production per $\mathrm{m}^{2}$, total annual production was $2.21 \mathrm{~g} \mathrm{C} \mathrm{m}^{-2} \mathrm{yr}^{-1}$, and production by cohorts was $1.23 \mathrm{~g} \mathrm{C} \mathrm{m}^{-2} \mathrm{yr}^{-1}$ for the 1980 cohort and $0.98 \mathrm{~g} \mathrm{C}^{-1}$ $\mathrm{m}^{-2} \mathrm{yr}^{-1}$ for the pre-1980 cohort (Kemp 1985, unpubl.). Daily production averaged over the year was $6.05 \mathrm{mg}$

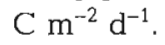

Temperature and salinity had a significant but comparatively small effect on weight-specific respiration (ANOVA; Table 1), and therefore were not considered in estimating annual respiration. Varying body weight resulted in an order of magnitude decrease in weightspecific respiration over the size range examined (Fig. 1). The regression equation of respiration $\left(\mathrm{R}, \mu \mathrm{l} \mathrm{O} \mathrm{O}_{2} \mathrm{mg}\right.$ $A F D W^{-1} h^{-1}$ ) versus weight ( $W$, mg AFDW) at $12^{\circ} \mathrm{C}_{\text {, }}$ combining measurements at 3 salinities, was:

$\log (R)=-0.8131 \log (W)-0.0221\left(n=90, r^{2}=0.75\right)$.

Annual respiration was calculated using this regression and the number and estimated mean weight of individuals of each cohort in each sample. Total respiration (Table 2) was equivalent to the release of $88.63 \mathrm{~g}$
$\mathrm{C} \mathrm{m}^{-1} \mathrm{yr}^{-1}$ or $4.84 \mathrm{~g} \mathrm{C} \mathrm{m}^{-2} \mathrm{yr}^{-1}\left(13.27 \mathrm{mg} \mathrm{C} \mathrm{m}^{-2} \mathrm{~d}^{-1}\right)$. The annual respiration by cohorts was $3.55 \mathrm{~g} \mathrm{C} \mathrm{m}^{-2} \mathrm{yr}^{-1}$ for the pre-1980 cohort and $1.30 \mathrm{~g} \mathrm{C} \mathrm{m}^{-2} \mathrm{yr}^{-1}$ for the 1980 cohort. The estimated annual carbon requirement of Euzonus mucronata in 1980-1981, equal to the sum of respiration and production, was $7.05 \mathrm{~g} \mathrm{C} \mathrm{m}^{-2} \mathrm{yr}^{-1}$. The mean carbon requirement per day over the course of

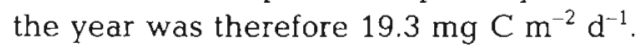

The regression coefficient of -0.813 is unusually high relative to most other fauna (typical values near -0.25 ). It is possible that a systematic bias in the response of different sized individuals to test conditions may have resulted in an inaccurately high coefficient. Possible explanations are inadequate equilibra-

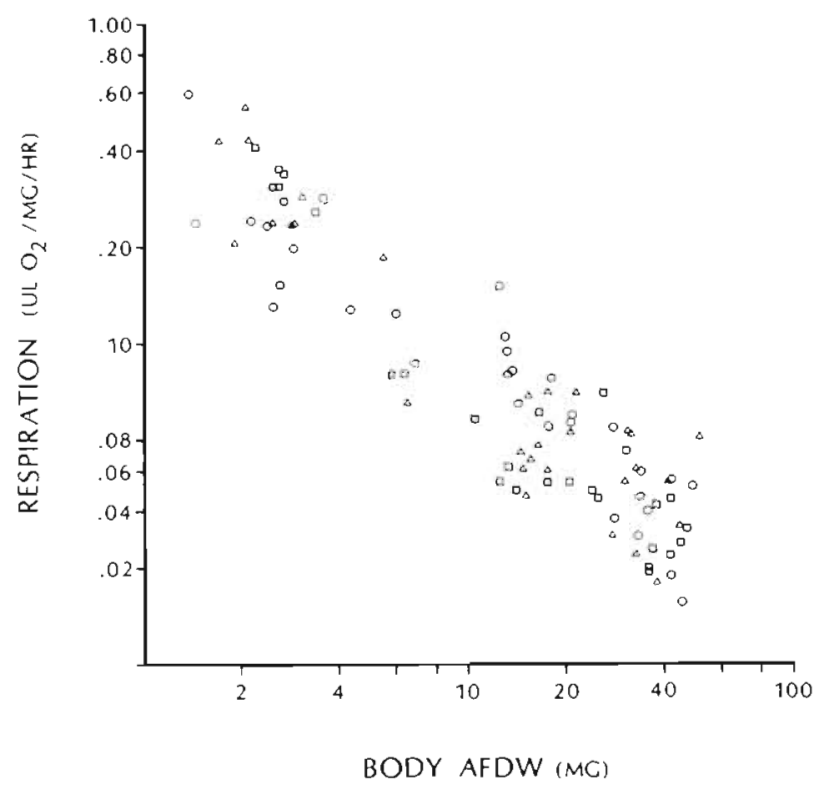

Fig. 1. Euzonus mucronata. Respiration $\left(\mu \mathrm{l} \mathrm{O}_{2} \mathrm{mg}^{-1}\right.$ body AFDW $\mathrm{h}^{-1}$ ) versus body AFDW at 3 salinities. (ㅁ) $6.5 \%$ salinity; $(\triangle) 16 \%$; (O) $32 \%$

Table 1. Euzonus mucronata. Mean respiration $\left(\mu \mathrm{l} \mathrm{O}_{2} \mathrm{mg}^{-1} \mathrm{AFDW} \mathrm{h} \mathrm{h}^{-1}\right.$ ) versus temperature and salinity, and ANOVA of data. Ten replicates per temperature-salinity combination

\begin{tabular}{|c|c|c|c|c|}
\hline $\begin{array}{c}\text { Salinity } \\
(\%)\end{array}$ & $9^{\circ} \mathrm{C}$ & $12{ }^{\circ} \mathrm{C}$ & $15^{\circ} \mathrm{C}$ & Mean \\
\hline 6.5 & $0.080 \pm 0.019$ & $0.083 \pm 0.014$ & $0.102 \pm 0.030$ & 0.088 \\
\hline 16.0 & $0.082 \pm 0.012$ & $0.103 \pm 0.020$ & $0.081 \pm 0.025$ & 0.089 \\
\hline 32,0 & $0.086 \pm 0.017$ & $0.165 \pm 0.042$ & $0.122 \pm 0.028$ & 0.124 \\
\hline Mean & 0.083 & 0.117 & 0.102 & 0.101 \\
\hline \multicolumn{5}{|c|}{ Analysis of variance } \\
\hline Factor & df & MS & F & $\mathrm{p}$ \\
\hline Temperature & 2 & 0.0112 & 8.24 & 0.001 \\
\hline Salinity & 2 & 0.0115 & 8.46 & 0.001 \\
\hline $\mathrm{T} \times \mathrm{S}$ & 4 & 0.0036 & 2.65 & 0.05 \\
\hline Error & 81 & 0.00136 & & \\
\hline
\end{tabular}


Table 2. Euzonus mucronata. Annual respiration estimates. $\mathrm{N} \mathrm{m}^{-1}$. mean number of individuals per meter; $\mathrm{L}$ : mean length ( $\mathrm{cm}$ ); AFDW: mean ash-free dry weight (mg) per individual; $\mathrm{R}$ : respiration $\left(\mu \mathrm{l} \mathrm{mg}^{-1}\right.$ AFDW h $\left.\mathrm{h}^{-1}\right)$; $\mathrm{R}(\mathrm{int})$ : total respiration $\left(\mu \mathrm{l} \times 10^{6}\right)$ during interval between sampling; $C$ : carbon respired per interval $\left(\mathrm{g} \mathrm{C} \mathrm{m}^{-1}\right) ; \mathrm{C}^{\prime}$ : carbon respired based on respiration regression coefficient of Dangott \& Terwilliger (1986)

\begin{tabular}{|c|c|c|c|c|c|c|c|}
\hline Date sampled & $\mathrm{N} \mathrm{m}^{-1}$ & $L$ & AFDW & $\mathrm{R}$ & $\mathrm{R}(\mathrm{int})$ & $\mathrm{C}$ & $C^{\prime}$ \\
\hline \multicolumn{8}{|l|}{1980 cohort } \\
\hline 15 Jun-19 Jul 1980 & 21863 & 0.431 & 0.009 & 45.54 & 6.37 & 3.07 & 0.48 \\
\hline 19 Jul-2 Sep 1980 & 29498 & 0.802 & 0.054 & 10.25 & 17.63 & 8.50 & 2.70 \\
\hline 2 Sep-17 Sep 1980 & 24561 & 1.081 & 0.130 & 5.00 & 5.74 & 2.77 & 1.24 \\
\hline 17 Sep-23 Oct 1980 & 18489 & 1.462 & $0.31 \overline{7}$ & 2.42 & 12.25 & 5.09 & 3.24 \\
\hline 23 Oct-28 Dec 1980 & 15819 & 1.855 & 0.639 & 1.37 & 21.90 & 10.56 & 8.86 \\
\hline 28 Dec-5 Mar 1981 & 18791 & 1.851 & 0.636 & 1.37 & 26.36 & 12.72 & 10.65 \\
\hline 5 Mar-11 May 1981 & 18132 & 1.974 & 0.769 & 1.18 & 27.16 & 13.09 & 11.81 \\
\hline \multirow[t]{2}{*}{11 May-22 Jun 1981} & 16651 & 2.581 & 1.697 & 0.62 & 17.19 & 8.29 & 10.20 \\
\hline & & & & Total $=$ & 134.6 & 64.89 & 49.18 \\
\hline \multicolumn{8}{|l|}{ Pre- 1980 cohort } \\
\hline 15 Jan-19 Jul 1980 & 3273 & 3.837 & 5.472 & 0.24 & 3.18 & 1.53 & 2.98 \\
\hline 19 Jul-2 Sep 1980 & 2286 & 4.009 & 6.228 & 0.22 & 3.38 & 1.63 & 3.35 \\
\hline 2 Sep-17 Sep 1980 & 3493 & 3.832 & 5.448 & 0.24 & 1.64 & 0.79 & 1.54 \\
\hline 17 Sep-23 Oct 1980 & 3676 & 3.856 & 5.552 & 0.24 & 4.16 & 2.00 & 3.92 \\
\hline 23 Oct-28 Dec 1980 & 3365 & 4.662 & 9.727 & 0.15 & 7.75 & 3.73 & 9.12 \\
\hline 28 Dec $1980-5$ Mar 1981 & 3904 & 4.790 & 10.540 & 0.14 & 9.27 & 4.47 & 11.28 \\
\hline 5 Mar-11 May 1981 & 4928 & 4.628 & 9.516 & 0.15 & 11.82 & 5.70 & 13.82 \\
\hline \multirow[t]{2}{*}{11 May-22 Jun 1981} & 53.58 & 5.101 & 12.690 & 0.12 & 8.06 & 3.88 & 10.53 \\
\hline & & & & Total $=$ & 49.26 & 23.74 & 56.54 \\
\hline
\end{tabular}

tion time for larger individuals, or a behavioral response of larger individuals to the small respirometer flasks. Dangott \& Terwilliger (1986) report a regression coefficient of -0.42 for an Oregon (USA) population of Euzonus mucronata, using starved adults in seawater without sand. Respiration (as equivalent $C$ release) was also calculated using this value (Table 2), yielding annual respiration estimates of 2.69 and $3.09 \mathrm{~g} \mathrm{C} \mathrm{m}^{-2} \mathrm{yr}^{-1}$ for the 1980 and pre-1980 cohorts, respectively, totalling $5.78 \mathrm{~g} \mathrm{C} \mathrm{m}^{-2} \mathrm{yr}^{-1}$. The annual carbon requirement using their regression coefficient is increased slightly to $7.99 \mathrm{~g} \mathrm{C} \mathrm{m}^{-2} \mathrm{yr}^{-1}$ or $21.9 \mathrm{mg} \mathrm{C}$ $\mathrm{m}^{-2} \mathrm{~d}^{-1}$.

\section{Bacterial biomass and production}

On 7 December 1982 mean bacterial cell volume was $0.128 \mu^{3}$; no substantial variation in cell size with tidal elevation was observed. A conversion factor of $2.816 \times 10^{-14} \mathrm{~g} \mathrm{C} \mathrm{cell}^{-1}$ (cell volume $\times 0.22 \mathrm{~g} \mathrm{C} \mathrm{cm}^{-3}$ ) was used to convert all cell counts to carbon biomass. Including samples taken on 4 August 1982 and 7 April 1983 (Table 3), the average value of mean cell densities was $7.75 \times 10^{7}$ cells $\mathrm{g}^{-1}$, and the equivalent mean biomass was $2.18 \mu \mathrm{g} \mathrm{C} \mathrm{g}^{-1}$ sand or $0.55 \mathrm{~g} \mathrm{C} \mathrm{m}^{-2}$ to $15 \mathrm{~cm}$ depth.

The incorporation of isotope in uptake experiments was corrected for a $39.6 \%$ recovery efficiency estimated from the recovery of added Escherischia coli DNA. Of the $60.4 \%$ of DNA not recovered on the filter, $10.5 \%$ of added DNA was not recovered from the sand and $44.3 \%$ of the remaining added DNA passed through the filter.

Production was corrected for isotope dilution in each sample (Fig. 2) by the method of Moriarty \& Pollard (1981). At $11^{\circ} \mathrm{C}$, daily carbon production was 7.53 to $16.48 \%$ of the standing bacterial biomass, resulting in estimated turnover times ranging from 6.1 to $13.3 \mathrm{~d}$ with a mean turnover time of $10 \mathrm{~d}$ (Table 4).

\section{DISCUSSION}

\section{Bacterial production}

Bacterial turnover time on 7 December 1982 averaged $10 \mathrm{~d}$ at ambient temperature $\left(11^{\circ} \mathrm{C}\right)$. This is of the same order of magnitude as turnover times reported for sediment bacteria in varied sediment types at temperatures ranging from 17 to $29^{\circ} \mathrm{C}$ (Table 5), despite the much lower densities of bacterial populations measured in this low-organic beach sand. The limited information available indicates that benthic bacterial turnover rates vary seasonally by much less than an order of magnitude (Moriarty \& Pollard 1981). Based on 
the 7 December turnover time and mean cell volume, and on the mean bacterial abundance on 3 sample dates, daily carbon production on this beach was 0.22 $\mu \mathrm{g} \mathrm{C} \mathrm{g}{ }^{-1}$ sand $\mathrm{d}^{-1}$ or $55 \mathrm{mg} \mathrm{C} \mathrm{m}^{-2} \mathrm{~d}^{-1}$.

\section{Utilization of bacteria by Euzonus mucronata}

The average daily carbon requirement of Euzonus mucronata (19.3 or $21.9 \mathrm{mg} \mathrm{C} \mathrm{m} \mathrm{C}^{-2}$, depending on the method of calculating respiration) was about 35 to $40 \%$ of the estimated bacterial production. The carbon requirement estimate does not include mucus secretion or excretory losses and should be considered a minimum estimate. If assimilation efficiency is about $50 \%$, the study population of E. mucronata could derive its daily carbon requirements from bacteria by ingesting most of the bacterial production.

The amount of bacterial production ingested daily was estimated from measured gut clearance time and sand content. Because clearance rate and gut content (as percent of body weight) were not correlated with body weight, total ingestion may be estimated from the mean biomass of Euzonus mucronata. Based on continuous feeding throughout the year and an annual mean biomass of $2.5 \mathrm{~g}$ AFDW $\mathrm{m}^{-2}$ (Kemp 1985 , unpubl.), the average ingestion of sand by the 1980-81 population would be $1.95 \mathrm{~kg}$ dry sand $\mathrm{m}^{-2} \mathrm{~d}^{-1}$, equiva-

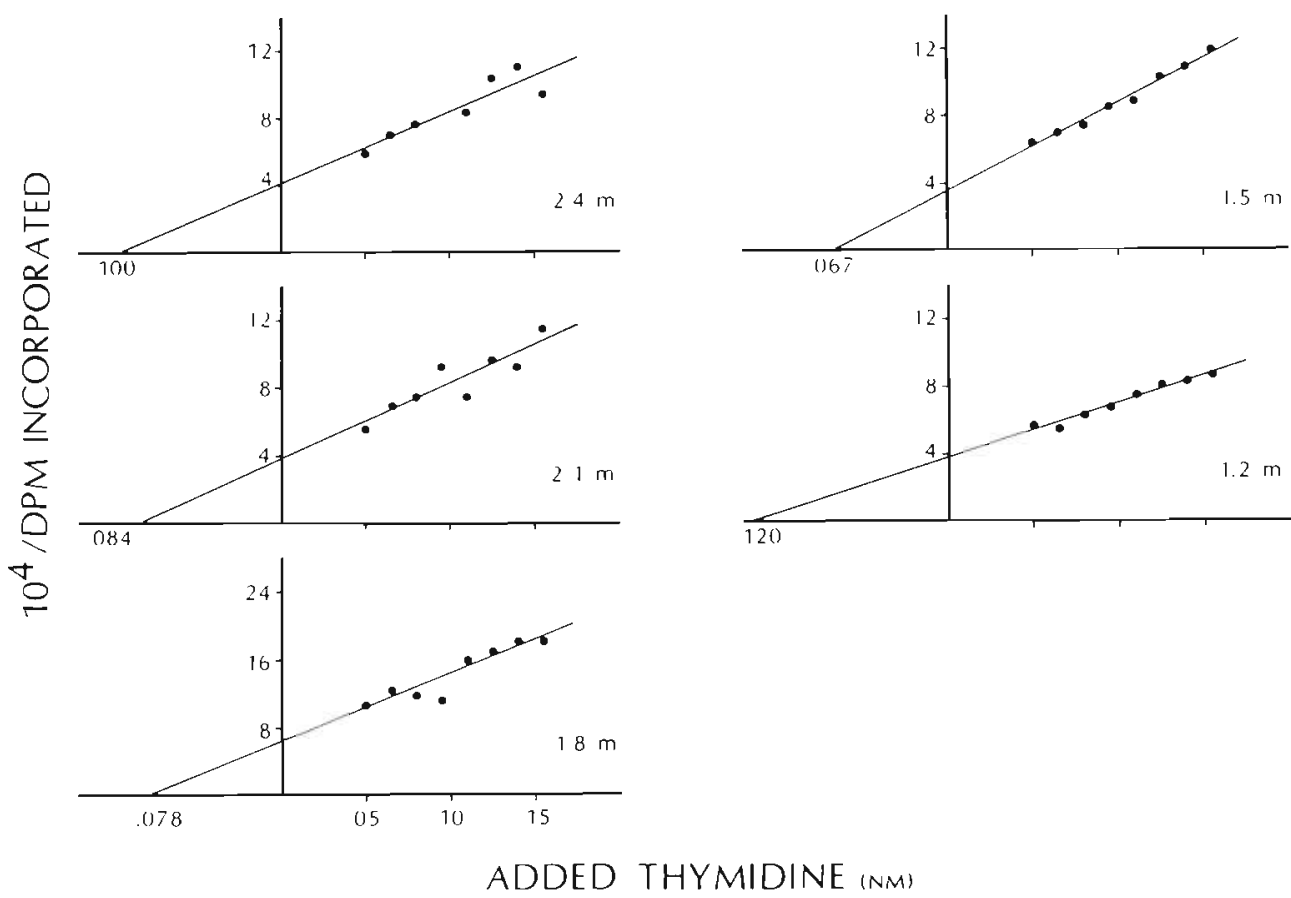

Table 3. Mean abundance and equivalent biomass of bacteria on 4 Aug 1982, 7 Dec 1982, and 7 Apr 1983

\begin{tabular}{|lccc|}
\hline $\begin{array}{l}\text { Sampling } \\
\text { date }\end{array}$ & Cells g & \\
& & & \\
\hline 4 Aug 1982 & 12.03 & 3.39 & 0.84 \\
7 Dec 1982 & 6.07 & 1.71 & 0.42 \\
7 Apr 1983 & 5.17 & 1.46 & 0.36 \\
- Assuming cell volume $=0.128 \mathrm{um}^{3}$ & \\
\hline
\end{tabular}

Table 4. Bacterial production and biomass data for 7 Dec 1982. Cell abundance and production expressed per g dry sand

\begin{tabular}{|c|c|c|c|c|}
\hline $\begin{array}{l}\text { Elevation } \\
\quad(\mathrm{m})\end{array}$ & $\begin{array}{c}\text { Cells } \\
\mathrm{g}^{-1} \times 10^{7}\end{array}$ & $\mu \mathrm{gC} \mathrm{g}^{-1}$ & $\underset{\mathrm{h}^{-1} \mathrm{~g}^{-1} \times 10^{5}}{\text { Cells }}$ & $\begin{array}{l}\text { Turnover } \\
\text { time (d) }\end{array}$ \\
\hline+2.4 & 4.29 & 1.21 & 2.95 & 6.07 \\
\hline$+2.1^{\circ}$ & 6.78 & 1.91 & 2.71 & 10.43 \\
\hline$+1.8^{\circ}$ & 4.38 & 1.23 & 1.53 & 11.93 \\
\hline+1.5 & 7.43 & 2.09 & 2.33 & 13.29 \\
\hline \multirow[t]{2}{*}{+1.2} & 7.47 & 2.10 & 3.84 & 8.10 \\
\hline & & & $\begin{array}{r}\text { Mean }= \\
\text { SD }=\end{array}$ & $\begin{array}{l}9.96 \\
2.91\end{array}$ \\
\hline
\end{tabular}

- Upper and lower Euzonus band 
Table 5. Reported turnover times for sediment bacteria

\begin{tabular}{|lcccc|}
\hline \multicolumn{1}{c}{ Site type } & Turnover time (h) & No. cells $\times 10^{9}$ & $\mathrm{~T}^{\circ} \mathrm{C}$ & Source \\
\hline Sand microcosms, high organic input & $50-1000$ & $15-100 \mathrm{ml}^{-1}$ & 20 & Alongi (1985) \\
Subtidal sand & $170-2100$ & $0.07-4.1 \mathrm{ml}^{-1}$ & $19-20$ & Fallon et al. (1983) \\
Salt marsh & $2800-4400$ & $3-8.1 \mathrm{ml}^{-1}$ & $19-20$ & Fallon et al. (1983) \\
River, surface sand & 816 & $\mathrm{na}$ & na & Findlay \& Meyer (1983) \\
Sand beach & 100 & $1 \mathrm{~g}^{-1}$ & 21 & Meyer-Reil et al. (1980) \\
Seagrass bed & $48-180$ & $0.6-1 \mathrm{~g}^{-1}$ & $17-24$ & Moriarty \& Pollard (1981) \\
Seagrass bed & 5.5 & $2 \mathrm{~g}^{-1}$ & 31 & Moriarty \& Pollard (1981) \\
Seagrass bed & 480 & $1.4 \mathrm{~g}^{-1}$ & 17 & Moriarty \& Pollard (1982) \\
Coral sand flat & 50 & $\mathrm{na}$ & 29 & Moriarty et al. (1985) \\
Coral sand flat & 384 & $\mathrm{na}$ & 23 & Moriarty et al. (1985) \\
High-energy sand beach & 240 & $0.05-0.12 \mathrm{~g}^{-1}$ & 11 & Present study \\
na: data not available in report & & & & \\
\hline
\end{tabular}

lent to 2.9 turnovers $\mathrm{yr}^{-1}$ of the sand to a depth of 15 $\mathrm{cm}$. Given a mean bacterial biomass of $2.18 \mu \mathrm{g} \mathrm{C} \mathrm{g}^{-1}$ dry sand, $4.3 \mathrm{mg} \mathrm{C} \mathrm{m} \mathrm{m}^{-2} \mathrm{~d}^{-1}$ would be ingested by the study population of E. mucronata, or about $20 \%$ of the average daily carbon requirement. This could be increased by selective feeding on sand with higher bacterial densities, such as exist at the surface of muddy sediment (Rublee 1982). Since the sand is mixed by wave action several times during the $10 \mathrm{~d}$ bacterial turnover time, there is little reason to expect any substantial gradient in bacterial density in this high-energy environment. Furthermore, selectivity in deposit-feeders rarely alters the rate of ingestion of organic matter by more than a factor of 2 (Cammen $1980 b)$. Considering that feeding is probably not continuous and the efficiency of assimilation of bacteria by macrofauna is typically near $50 \%$, bacteria probably supply less than $10 \%$ of the carbon requirements of $E$. mucronata. Conversely, the study population of $E$. mucronata would ingest less than $10 \%$ (probably less than $5 \%$ ) of bacterial production each day.

Assimilation of bacteria would provide nitrogen-rich material. If the carbon: nitrogen ratios of Euzonus.mucronata and bacteria are about equal and E. mucronata assimilates bacterial nitrogen and carbon with about equal efficiencies, the estimated ingestion of bacteria would provide less than $20 \%$ of the average daily nitrogen requirement for tissue production by $E$. mucronata. Slow-growing adults may have lower nitrogen requirements than juveniles, and consequently obtain relatively more of their required nitrogen from bacteria.

Euzonus mucronata is unable to utilize bacteria as a principal food source because of the low concentration of bacterial biomass $\left(0.5\right.$ to $1.2 \times 10^{8}$ cells $\left.^{-1}\right)$. When extrapolated to other sediments and other macrofauna, this conclusion has significant implications for possible trophic relationships between bacteria and benthic launa. The sediment-processing rate of $E$. mucronata measured in this study is very much higher than for other deposit-feeders of similar size. Depositfeeders with lower sediment processing capabilities presumably would require even higher bacterial densities to subsist on bacterial carbon, approaching $10^{10}$ cells $g^{-1}$. Bacterial abundances of this magnitude occur in organic-rich sediment (e.g. Rublee 1982, Montagna 1984). Bacterial carbon is therefore probably not important to the nutrition of other deposit-feeding macrofauna of exposed sand beaches, and is likely to be important to macrofauna in other environments only when bacteria are very abundant. However, since sediment ingestion rates of deposit-feeders generally decline with increasing sediment organic content (Cammen 1980b), it is uncertain whether bacterial biomass could be an important carbon source even when very abundant.

\section{Impact of macrofaunal grazing and fate of bacterial production}

Daily bacterial production was several times greater than the production of Euzonus mucronata, the dominant macrofaunal species at the study site, despite the low bacterial abundance. Given that bacterial turnover times are apparently independent of bacterial abundance, bacterial production in sediment with higher bacterial numbers would be correspondingly higher and would greatly exceed macrofaunal production. For example, annual production of deposit-feeding macrofaunal species varies from about 1 to $10 \mathrm{~g} \mathrm{AFDW} \mathrm{m}^{-2}$ $\mathrm{yr}^{-1}$ (Wolff 1983), roughly equivalent to 1.4 to $14 \mathrm{mg} \mathrm{C}$ $\mathrm{m}^{-2} \mathrm{~d}^{-1}$. In comparison, bacterial production in the present study was $55 \mathrm{mg} \mathrm{C} \mathrm{m} \mathrm{C}^{-1}$ to $15 \mathrm{~cm}$ depth, and Fallon et al. (1983) calculated bacterial production rates of 100 to $800 \mathrm{mg} \mathrm{C} \mathrm{m}^{-2} \mathrm{~d}^{-1}$ in the upper $25 \mathrm{~cm}$ of 
nearshore sandy sediments. It is unlikely that macrofaunal deposit-feeders would remove more than a few percent of bacterial production in most sediments, as was shown here for E. mucronata, although abundant surface-feeding macrofauna could remove a substantial fraction of bacterial production in a restricted surface layer. For example, Moriarty et al. (1985) calculated that a surface-feeding holothurian could remove as much as 10 to $40 \%$ surface (to $0.5 \mathrm{~cm}$ ) bacterial production per day in summer on coral reef sand flats. In most sediments, the fate of the majority of benthic bacterial production is unknown.

In pelagic systems bacterial production may be largely consumed by microflagellates (Ducklow 1983) which reproduce rapidly (Sherr \& Sherr 1983) and are capable of responding to fluctuations in bacterial numbers. These microflagellate grazers are preyed upon by zooplankton, thus providing an indirect route of transfer of bacterial production to macrozooplankton. An analogous microbial food chain of bacteria, protozoan grazers, and possibly meiofaunal or macrofaunal predators may exist in sediment and account for the remainder of bacterial production. Although very little quantitative data exist on the grazing of benthic Protozoa on bacteria, Fenchel (1975) calculated for a tundra pond that Protozoa grazed approximately $8 \%$ of the standing stock of benthic bacteria each day. Maintaining bacterial numbers would require a bacterial turnover time of $12 \mathrm{~d}$ or less, which is comparable to turnover times reported in recent literature. Though these estimates are suggestive of the potential significance of Protozoa as regulators of bacterial production, the importance and trophic position of Protozoa in benthic food chains remains unknown.

Meiofaunal grazing directly on bacteria may remove a substantial part of bacterial production. Montagna (1984) determined that meiofauna of a Spartina alterniflora saltmarsh removed $3 \%$ of the sediment bacteria per hour, thus requiring a bacterial turnover time of $30 \mathrm{~h}$ to maintain the bacterial population in equilibrium with meiofaunal grazing. Some higher estimates of bacterial production would suggest that bacterial turnover is rapid enough to outpace this intensity of meiofaunal grazing (Montagna 1984). However, most estimates indicate bacterial turnover times substantially longer than $30 \mathrm{~h}$ (Table 5), indicating that meiofaunal grazing may sometimes control bacterial numbers. Alongi (1985), in contrast, found that bacterial numbers and growth rate were little affected by the presence of meiofauna under the conditions of high organic inputs in laboratory microcosms. The role of meiofauna as bacterial grazers is likely to be complex and variable between environments.

In some environments, part of bacterial production would ultimately be available to macrofauna through predation on meiofauna or Protozoa. Although macrofaunal and meiofaunal food chains on intertidal sand beaches may operate independently (McLachlan 1983), predation by epibenthic invertebrate and fish predators on meiofauna (Coull \& Palmer 1984) is important and may represent a major trophic link in sand and mud sediments.

Some of these transfer routes have been incorporated in conceptual models (e.g. Tenore \& Rice 1980) but remain unquantified. Given that bacterial production greatly exceeds macrofaunal production in most sediments and most of bacterial production is not directly consumed by macrofauna, future studies of the basis of benthic secondary production should place more emphasis on microbial and meiofaunal food chains and their linking to macrofaunal food chains.

Acknowledgements. The author gratefully acknowledges support from NSF DCB 84-16602 to Dr. J. Siebenaller and the assistance of $\mathrm{C}$. Holcombe with drafting. The manuscript benefited greatly from the comments of Dr. J. Gonor and anonymous reviewers. This is contribution No. 569 of the University of Georgia Marine Institute.

\section{LITERATURE CITED}

Alongi, D. M. (1985). Effect of physical disturbance on population dynamics and trophic interactions among microbes and meiofauna. J. mar. Res. 43: 351-364

Baker, J. H., Bradnam, L. A. (1976). The role of bacteria in the nutrition of aquatic detritivores. Oecologia (Berl.) 24: 95-104

Bosworth, W. S. (1976). Biology of the genus Eohaustorius (Amphipoda: Haustoriidae) on the Oregon Coast. Ph. D. thesis, Oregon State University

Bratbak, G., Dundas, I. (1974). Bacterial dry matter content and biomass estimations. Appl. environ. Microbiol. 48: $755-757$

Burton, K. (1956). A study of the conditions and mechanism of the diphenylamine reaction for the colorimetric estimation of deoxyribonucleic acid. Biochem. J. 62: 315-323

Cammen, L. M. (1980a). The significance of microbial carbon in the nutrition of the deposit feeding polychaete Nereis succinea. Mar. Biol. 61: 9-20

Cammen, L. M. (1980b). Ingestion rate: an empirical model for aquatic deposit feeders and detritivores. Oecologia (Berl.) 44: 303-310

Carman, K. R., Thistle, D. (1985). Microbial food partitioning by three species of benthic copepods. Mar. Biol. 88: $143-148$

Coull, B. C., Palmer, M. A. (1984). Field experimentation in meiofaunal ecology. Hydrobiologia 118: 1-19

Craven, D. B., Karl, D. M. (1984). Microbial RNA and DNA. synthesis in marine sediments. Mar. Biol. 83: 129-139

Dale, N. G. (1974). Bacteria in intertidal sediments: factors related to their distribution. Limnol. Oceanogr. 19: $509-518$

Dangott, L. J., Terwilliger, R. C. (1986). The role of extracellular hemoglobins in the oxygen consumption of the burrowing polychaete, Euzonus mucronata (Treadwell). J. exp. mar. Biol. Ecol. 97: 193-204 
Ducklow, H. W. (1983). Production and fate of bacteria in the oceans. Bioscience 33: 494-501

Eikenberry, A. B. (1966). A study of the vertical and horizontal migrations of Euzonus (Thoracophelia) mucronata (Treadwell 1914) on Pacific coast beaches with regard to environmental factors. M.S. thesis, University of the Pacific, Stockton

Fallon, R. D, Newell, S. Y., Hopkinson, C. S. (1983). Bacterial production in marine sediments: will cell-specific measures agree with whole-system metabolism? Mar. Ecol. Prog. Ser. 11: 119-127

Fenchel, T. (1970). Studies on the decomposition of organic detritus derived from the turtle grass Thalassia testudinum. Limnol. Oceanogr. 15: 14-20

Fenchel, T. (1975). The quantitative importance of the benthic microfrauna of an arctic tundra pond. Hydrobiologia 46: $445-464$

Fenchel, T., Blackburn, T. H. (1979). Bacteria and mineral cycling. Academic Press, London

Findlay, S., Meyer, J. L. (1983). Significance of bacterial biomass and production as an organic carbon source in lotic detrital systems. Bull. mar. Sci. 35: 318-325

Findlay, S., Meyer, J. L., Smith, P. J. (1984). Significance of bacterial biomass in the nutrition of a freshwater isopod (Lirceus sp.) Oecologia (Berl.) 63: 38-42

Fuhrman, J. A., Azam, F. (1982). Thymidine incorporation as a measure of heterotrophic bacterioplankton production in marine surface waters: evaluation and field results. Mar. Biol. 66: 109-120

Gonor, J. J., Thum, A. B., Elvin, D. W. (1970). Inshore sea surface temperature and salinity conditions at Agate Beach, Yaquina Bay, and Whale Cove, Oregon, in 1970 Tech. Report to Office of Naval Res., ref. 70-44, Nov 1970 Oregon State University

Hammond, L. S. (1983). Nutrition of deposit-feeding holothuroids and echinoids (Echinodermata) from a shallow reef lagoon, Discovery Bay, Jamaica. Mar. Ecol. Prog. Ser. 10: 297-305

Hargrave, B. T. (1970a). The utilization of benthic microflora by Hyalella azteca (Amphipoda). J. Anim. Ecol. 39: $427-437$

Hargrave, B. T. (1970b). The effect of a deposit-feeding amphipod on the metabolism of benthic microflora. Limnol. Oceanogr. 15: 21-30

Hobbie, J. E., Daley, R. J., Jasper, S. (1977). Use of nucleopore filters for counting bacteria by fluorescence microscopy. Appl. environ. Microbiol. 3: 1225-1228

Hughes, J. E. (1982). Life history of the sandy beach amphipod Dogielinotus loquax (Crustacea Dogielinotidae) from the outer coast of Washington, USA Mar. Biol. 71: 167-175

Hylleberg, J. (1975). Selective feeding by Abarenicola pacifica with notes on Abarenicola vagibonda and a concept of gardening in lugworms. Ophelia 14: 113-137

Jensen, K. T., Siegismund, H. R. (1980). The importance of diatoms and bacteria in the diet of Hydrobia species. Ophelia 1 (Suppl.): 193-199

Kemp, P. F. (1979). Dispersion of the sandy-beach amphipod Echaustorius brevicuspis Bosworth. M.S. thesis, Oregon State University

Kemp, P. F. (1985). Life history, production and food resources of the deposit-feeding polychaete Euzonus mucronata on an Oregon coastal sand beach. Ph. D. thesis, Oregon State University

Kemp, P. F. (1986). Direct uptake of detrital carbon by the deposit-feeding polychaete Euzonus mucronata (Treadwell). J. exp. mar. Biol. Ecol. 99: 49-61
Levinton, J. S., Bianchi, T. S. (1981). Nutrition and food limitation of deposit-feeders. I. The role of microbes in the growth of mud snails (Hydrobiidae). J. mar. Res. 39: 531-545

Levinton, J. S., Bianchi, T. S., Stewart, S. (1984). What is the role of particulate organic matter in benthic invertebrate nutrition? Bull. mar. Sci. 35: 270-282

McLachlan, A. (1983). Sand beach ecology - a review. In: McLachlan, A., Erasmus, T. (ed.) Sandy beaches as ecosystems. Junk Publishers, Boston, p. 321-380

Meyer-Reil, L.-A., Dawson, R., Liebezeit, G., Tiedge, H (1978). Fluctuations and interactions of bacterial activity in sandy beach sediments and overlying waters. Mar. Biol. 48: $161-171$

Meyer-Reil, L.-A., Bolter, M., Dawson, R., Liebezeit, G. Szwerinski, H., Wolter, K. (1980). Interrelationship between microbial and chemical parameters of sandy beach sediments, a summer aspect. Appl. environ. Microbiol. 39: 797-802

Montagna, P. A. (1982). Sampling design and enumeration statistics for bacteria extracted from marine sediments Appl. environ. Microbiol. 43: 1366-1372

Montagna, P. A. (1984). In situ measurement of meiobenthic grazing rates on sediment bacteria and edaphic diatoms. Mar. Ecol. Prog. Ser. 18: 119-130

Moriarty, D. J. W., Pollard, P. C. (1981). DNA synthesis as a measure of bacterial productivity in seagrass sediments. Mar. Ecol. Prog. Ser. 5: 151-156

Moriarty, D. J. W., Pollard, P. C. (1982). Diel variation of bacterial productivity in seagrass (Zostera capricorni) beds measured by thymidine incorporation into DNA Mar. Biol. 72: 165-173

Moriarty, D. J. W., Pollard, P. C., Hunt, W. G., Moriarty, D. M. Wassenberg, T. J. (1985). Productivity of bacteria and microalgae and the effect of grazing by holothurians in sediments on a coral reef flat. Mar. Biol. 85: 293-300

Morrison, S. J., White, D. C. (1980). Effects of grazing by estuarine gammaridean amphipods on the microbiota of allochthonous detritus. Appl. environ. Microbiol. 40: 659-671

Newell, R. C. (1965). The role of detritus in the nutrition of two marine deposit feeders, the prosobranch Hydrobia ulvae and the bivalve Macoma balthica. Proc. zool. Soc. Lond. 44: 25-45

Oliver, J. S., Slattery, P. N., Hulberg, L. W., Nybakken, J. W. (1980). Relationship between wave disturbance and zonation of benthic invertebrate communities along a subtidal high-energy beach in Monterey Bay, California. Fish. Bull. U. S. 78: 437-454

Phillips, N. W. (1984). Role of different microbes and substrate as potential suppliers of specific, essential nutrients to marine detritivores. Bull. mar. Sci. 35: 283-298

Pollard, P. C., Moriarty, D. J. W (1984). Validity of the tritiated thymidine method for estimating bacterial growth rates: measurement of isotope dilution during DNA synthesis. Appl. environ. Microbiol. 48: 1076-1083

Riemann, B., Nielsen, P., Jeppesen, M., Marcussen, B., Fuhrman, J. A. (1984). Diel changes in bacterial biomass and growth rates in coastal environments, determined by means of thymidine incorporation into DNA, frequency of dividing cells (FDC), and microautoradiography. Mar. Ecol. Prog. Ser. 17. 227-235

Rublee, P. A. (1982). Seasonal distribution of bacteria in salt marsh sediments in North Carolina. Estuar. coast. Shelf Sci. 15: $67-74$

Sherr, E. B., Sherr, B. F. (1983). Double-staining epifluorescence technique to assess frequency of dividing cells and 
bacterivory in natural populations of heterotrophic microprotozoa. Appl. environ. Microbiol. 46: 1388-1393

Smith, B. D., Cabot, E. L., Foreman, R. E. (1985). Seaweed detritus versus benthic diatoms as important food resources for two dominant subtidal gastropods. J. exp. mar. Biol. Ecol. 92: 143-156

Stuart, V., Head, E. J. H., Mann, K. H. (1985). Seasonal changes in the digestive enzyme levels of the amphipod Corophium volutator (Pallas) in relation to diet. J. exp. mar. Biol. Ecol. 88: 243-256

Tenore, K. R., Rice, D. L. (1980). A review of trophic factors affecting secondary production of deposit-feeders. In: Tenore, K. R., Coull, B. C. (ed.) Marine benthic dynamics.
University of South Carolina Press, Columbia, p. 325-340 Tenore, K. R., Cammen, L., Findlay, S. E. G., Phillips, N (1982). Perspectives of research on detritus: do factors controlling the availability of detritus depend on its source? J. mar Res. 40:473-490

Wetzel, R. L. (1977). Carbon resources of a benthic salt marsh invertebrates Nassarius obsoletus Say (Mollusca: Nassariidae). In: Wiley, M. (ed.) Estuarine processes, Vol. 2. Academic Press, New York, p. 293-308

Wolff, W. J. (1983). Estuarine benthos. In: Ketchum, B. H. (ed.) Ecosystems of the world, Vol. 26. Estuaries and enclosed seas. Elsevier, New York, p. 151-182

This article was presented by Professor C. H. Peterson; it was accepted for printing on December 17, 1986 